\title{
International Capital Flows in Club of Convergence
}

\author{
Ly Dai Hung* $\quad$ Nguyen Thi Thuy Hoan ${ }^{\dagger}$
}

October 29, 2020

\begin{abstract}
By a cross-section sample of 175 economies, we show that for a higher productivity growth rate, the net total capital inflows increase in the club of convergence but decrease in the club of unconvergence. The proximity to world technology frontier can explain the difference on the pattern of capital flows through its negative impact on the net total capital inflows. By an open multi-country overlapping generations (OLG) economy, we establish that a closer proximity to world technology frontier raises the wage rate, then accelerating the gross savings. Since the gap between domestic investment and savings constitutes the net total capital inflows, a closer proximity reduces the inflows of capital, as recorded by the evidence.
\end{abstract}

Keywords: Capital Flows, Productivity Growth, Relative Convergence. JEL Classifications: F15, F36, F43.

*Email: hunglydai@gmail.com. CEC Centre for Economic Information, Analysis and Forecasting, Vietnam Central Economic Commission, Hanoi, Vietnam. Thang Long Institute of Mathematics and Applied Sciences (TIMAS), Hanoi, Vietnam. Address: A4 Building, Nguyen Canh Chan street, Ba Dinh district, Ha Noi city, Viet Nam. We thank the Editor and two anonymous Reviewers for helpful comments.

${ }^{\dagger}$ Email: hoan.ntt89@gmail.com. State Securities Commission of Vietnam, Hanoi, Vietnam. Address: 234 Luong The Vinh street, Nam Tu Liem district, Ha Noi city, Viet Nam. 


\section{Introduction.}

Does an increase of productivity growth rate lead to more net total capital inflows ? The answers are mixed. The neoclassical growth model (Solow (1956)) implies that a higher productivity growth rate raises the investment demand, then generating more inflows of capital. The recent up-hill capital flows evidence (Prasad, Rajan and Subramanian (2007)), however, records that a country with a higher productivity growth rate tends to receive less inflows of capital. Therefore, there exists controversy between the theory and evidence on the international capital flows.

Figure 1: Pattern of International Capital Flows

Panel A: Club of Unconvergence

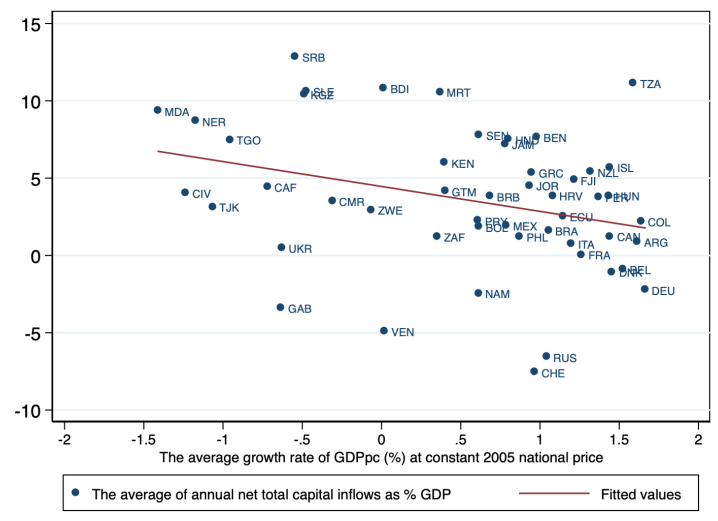

Panel B: Club of Convergence

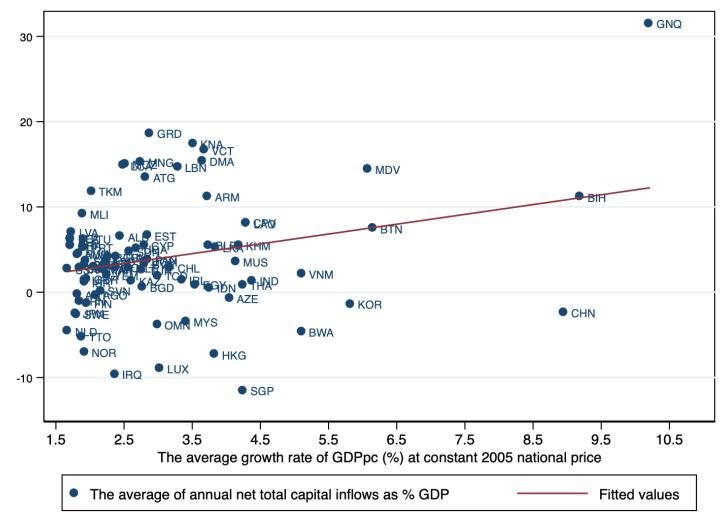

Figure (1) uncovers a clue on the solution for the controversy on the capital flows. Panel B gathers the economies with higher or equal productivity growth rate as the growth rate of United States, considered as the world technology leader (Aghion, Howitt and Mayer-Foulkes (2005)). These economies constitute to a club of convergence, since they converge to a common productivity growth rate in the long-run Aghion and Howitt \|(2008)). Panel A includes the economies with lower productivity growth rate than the rate of United States. They belong to a club of unconver- 
gence for their divergence from the growth rate of world technology leader. In the club of convergence, the net total capital inflows are increasing on the productivity growth rate, as implied by the neoclassical growth model. But, in the club of unconvergence, they are decreasing on the productivity growth rate, as recorded by the up-hill capital flows evidence. Therefore, a determinant of the convergence on productivity growth is also potential to account for the international capital flows.

We employ the proximity to world technology frontier to explain the international capital flows. The proximity is defined by Aghion and Howitt (2008) as the ratio of productivity level of an economy over the productivity level of the world technology leader. A closer proximity to world technology frontier means an increase of domestic productivity level. Then, the economy approaches the world technology leader.

Our empirical analysis on a sample of 175 economies shows that a closer proximity to world technology frontier is associated with less net total capital inflows. Meanwhile, it is associated with a lower productivity growth rate in the club of convergence but with a higher productivity growth rate in the club of unconvergence. Thus, the correlation between the productivity growth rate and the net total capital inflows is positive in the club of convergence but negative in the club of unconvergence.

Our multi-country overlapping generations (OLG) model establishes that a closer proximity to world technology frontier raises the gross savings. A huger savings stock, in turn, reduces the net total capital inflows, since the inflows of capital are the gap between domestic investment and savings.

The paper belongs to the literature on the cross-border capital flows (see Gourinchas and Rey (2014) for a recent survey). On Matsuyama (2004), an economy with a higher initial capital stock would have a higher investment demand, then, a higher long-run equilibrium level of capital. 
Thus, it receives the capital from the economy with low initial capital stock. In Caballero, Farhi and Gourinchas (2008), the abundant supply of assets reduces the assets price, then, raises the real interest rate. The high interest rate, in turn, attracts the capital from the economy with the scarcity of assets. Recently, Hung (2019b) shows that only the foreign direct investment capital tends to flow into the economies with high marginal product of capital.

Our paper complements to these aforementioned papers by emphasizing the proximity to world technology frontier as the key driver of international capital flows. We show that the capital would flow from the economy being closer to the world technology frontier to the one being further from the frontier.

Gourinchas and Jeanne (2013) document an allocation puzzle which is contradicted to the neoclassical growth model: a fast-growing economy tends to receive less inflows of capital. Benhima (2013) solves the puzzle by proving that the net total capital inflows depend on the net international investment position. They are decreasing on the productivity growth rate for the creditor economies but increasing on the productivity growth for the debtor economies. Coeurdacier, Guibaud and Jin (2015) show that, in the developing economies, for a tight credit constraint, the savings by middle-age agents are greater than the borrowings by young agents. Then, these economies can have a high productivity growth rate combined with the outflows of capital.

Our paper provides a solution for the allocation puzzle. Only for the economy with lower productivity growth rate than the world technology leader's growth rate, a higher productivity growth rate is associated with less net capital inflows. On other words, the allocation puzzle holds. Thus, the productivity growth rate of world technology leader separates the group of economies following the allocation puzzle from the group of economies 
following the prediction by the neoclassical growth model.

The paper is also related to the literature on the economic growth. Aghion and Howitt (2008) show that the convergence of productivity growth rate changes the type of innovation from the imitation to invention of new technology. Since the probability of successful invention is lower than the probability of successful imitation, the productivity growth rate is lower for an economy being closer to the world technology frontier.

Our paper, however, shows that the productivity growth rate follows an inverse U-shaped curve, by first increasing, then decreasing on the proximity to world technology frontier. Thus, we confirm that the result by Aghion and Howitt (2008) applies for the club of convergence. But we also uncover that, for the club of unconvergence, the benefit from the imitation of newly advanced technology can be large enough so that the growth rate accelerates for a closer proximity to the world technology frontier.

The convergence of productivity growth rate is analyzed on Acemoglu, Aghion and Zilibotti (2006). For an economy is closer to the world technology frontier, it changes from the investment-based strategy with large investment but little selection of high-skill managers to the innovationbased strategy with less investment but better selection of managers. And only the economy with the innovation-based strategy can converge to the world technology frontier. By an open-economy neoclassical growth model, Escot and Galindo (2000) show that the international capital flows can affect the convergence of productivity growth. Chatterjee and Naknoi (2010) record that the size of foreign capital transformed into domestic physical capital is large only in a few countries, but small in most of countries. Galindo and Escot (2000) provide an evidence that the capital flows can exert a positive impact on the convergence of productivity growth.

Unlike these papers, ours analyzes the impact of convergence of productivity growth rate on the cross-border capital flows. The convergence 
of productivity growth shapes the divergence of the pattern of capital flows in the club of convergence from their pattern in the club of unconvergence.

The paper is also related to the literature on the nexus between savings and economic growth. According to the permanent income hypothesis, a higher growth rate reduces the savings by the consumption smoothing mechanism. But recent empirical evidence also records that a higher growth rate can be associated with more savings. By a household data sample of United States, Carroll and Weil (1994) find that the households with predictably higher income growth save more than the households with predictably low income growth. On Parker and Preston (2005), the households can use their savings as a buffet stock to insure against the idiosyncratic shock to income, as implied by the precautionary motive. Recently, Hung (2019a) shows that financial friction can determine the savings. Then, a high growth rate can go along with low or high savings, depending on the severity of financial friction.

Our paper contributes on the literature by showing a new mechanism for the combination of high savings with low productivity growth rate. Along the convergence path to the world technology frontier, an economy has a lower productivity growth rate due to the lower probability of successful innovation, as implied by the endogenous growth theory Aghion and Howitt (2008)). It also has huger savings due to a lower income tax rate. Thus, an economy can have both low productivity growth rate and huge savings on the convergence path to the world technology frontier.

The paper processes as follows. Section (2) presents empirical evidence on the pattern of capital flows in both club of convergence and club of unconvergence. Next, section (3) builds up a theoretical model to analyze the role of proximity to world technology frontier on shaping the pattern of international capital flows. Finally, section (4) concludes and is followed by Appendix. 


\section{Evidence.}

We first present an empirical framework, including data description and model specification. Then, we compare the pattern of international capital flows in the club of convergence with the pattern in the club of unconvergence. Then, we show that the proximity to world technology frontier can account for the difference of capital flows pattern across two clubs.

\subsection{Framework.}

\subsubsection{Data.}

The dataset is a cross-section sample of 175 observations, covering both developing and advanced economies. Each variable is the value averaged over the 1980-2013 period.

The net total capital inflows (anegCA2y) are measured as the averaged negative value of current account per Gross Domestic Product (GDP). Scaling by GDP rules out the country-size effect on measuring the variable. The data is from the updated and extended version of dataset of net private and public capital flows constructed by Alfaro, Kalemli-Ozcan, and Volosovych (2014). The dataset is a panel sample for many economies, spanning from 1980 to 2013. Moreover, it also incorporates the data from various sources, from International Financial Statistics, and the external wealth of nations database by Lane and Milesi-Ferretti (2007).

The productivity growth rate ( $a G D P p c g r o w t h)$ is the averaged growth rate of GDP per capita, which is the real GDP at constant national 2005 prices divided by population. As implied by the neoclassical growth model (Solow (1956)), at the long-run equilibrium, the growth rate of output per capita is equal to the growth rate of total factor productivity. Moreover, the use of the growth rate of GDP per capita can overcome the controversy 
on the measurement of productivity level. This issue arises from the exact estimation of capital stock at the initial time, or from the dependence of productivity level on the capital and labor employed by firms. For data, we explore the real GDP from Pen World Table 8.1 (2015) and the population from the World Development Indicators.

The savings are the averaged gross savings, including both private and public savings. This variable is scaled by the Gross National Income (GNI) to preclude the country-size effect. We use the GNI, in stead of GDP, to illustrate more exactly the aggregate income since only the GNI accounts for the net foreign income gained on the international investment position. Moreover, the measurement is just in line with our theory. In theoretical model shown latter, the balanced public budget implies the coincidence of private and aggregate savings.

The proximity to world technology frontier (aproximity) for an economy is the averaged ratio of domestic productivity level over the productivity level of the leading economy at the world technology frontier. In Aghion and Howitt (2008), the leading economy drives the innovation process to push outward the world technology frontier. As Aghion, Howitt and Mayer-Foulkes (2005), we consider the United States as the economy at the world technology frontier, or the world technology leader. Then, a closer proximity to world technology frontier means that the domestic productivity level approaches the productivity level of the world technology leader. The data is from the Pen World Table 8.1.

The classification of club of convergence and club of unconvergence is based on the definition of relative convergence on Aghion and Howitt (2008). In particular, an economy converges successfully to the world technology frontier if its productivity growth rate is higher or at least equal to the growth rate of the world technology leader. By using this definition, we compute the ratio of productivity growth rate of an economy over the 
productivity growth rate of United States. If the ratio is greater or equal to 1 , the country belongs to the club of convergence. Otherwise, it is in the club of unconvergence. Note that there exists heterogeneity on each club of economies. As shown on Figure (1), the club of unconvergence includes both advanced economies such as Germany, Frances, and developing economies such as Kenya, Togo, Zimbabwe. And the club of convergence has also both advanced economies such as United Kingdoms, Spain, Japan and developing economies such as Vietnam, Bangladesh, Myanmar.

Table 1: Descriptive Statistics

\begin{tabular}{lccccc}
\hline \hline Variable & Obs & Mean & Std. Dev. & Min & Max \\
\hline \hline Net Total Capital Inflows (\%) (anegCA2y) & 175 & 4.781286 & 7.523386 & -13.81684 & 38.93217 \\
Productivity Growth Rate (\%) (aGDPpcgrowth) & 160 & 1.881766 & 1.852483 & -1.409037 & 10.20622 \\
Gross Savings (\%) (aS2GNI) & 172 & 20.03227 & 10.52318 & -32.23581 & 49.75173 \\
Proximity to World Technology Frontier (USA=1) (aproximity) & 107 & .6580185 & .2755747 & .1538925 & 1.542014 \\
\hline
\end{tabular}

Table (1) shows the descriptive statistics for the data sample. The net total capital inflows per GDP have a mean at $4.78 \%$ and a standard deviation at $7.5 \%$. In comparison with this variable, the productivity growth rate has both a lower mean at $1.8 \%$ and a less deviation at $1.85 \%$ while the gross savings have a much higher mean at $20 \%$ and a larger deviation at $10.5 \%$. The proximity to world technology frontier also exhibits a quite large standard deviation at 0.27 from the lowest value at 0.15 to the highest one at 1.5. Therefore, the data set offers rich variation for exploring the patterns of international capital flows.

\subsubsection{Model.}

We carry out the empirical regression by two steps. First, we regress the net total capital inflows on the productivity growth rate. This step shows the pattern of international capital flows. Second, we regress the net total capital inflows, gross savings and the productivity growth rate 
on the proximity to world technology frontier. This step illustrates the dependence of these variables on the proximity to world technology frontier. The combination of two steps investigates the role of the proximity to world technology frontier on determining the dependence pattern of net total capital inflows on the productivity growth rate.

The choice of independent variables in each step ensures a parsimonious model to investigate the net total capital inflows. Alfaro, Kalemli-Ozcan and Volosovych (2008) employ only two variables, including the output per capita and institutional quality to explain the reason why the capital does not flow from the rich to poor countries. In particular, for the first step, the regression equation follows a quadratic function on the full sample, while a linear function on each sub-sample.

$$
\begin{aligned}
& \text { anegCA2y } y^{j}=\alpha+\beta . a G D P p c g r o w t h^{j}+\gamma \cdot\left(a G D P \text { pcgrowt } h^{j}\right)^{2}+u^{j}(1) \\
& \text { anegCA2y } y^{j}=\alpha+\beta . a G D P \text { pcgrowth } h^{j}+u^{j}
\end{aligned}
$$

For the second step, the regression equation follows a linear function on both full sample and on each sub-sample.

$$
\begin{aligned}
\operatorname{anegCA2y^{j}} & =\alpha+\beta \text {.aproximity } \\
\text { aS2GNI } & =u^{j} \\
& =\alpha+\beta . \text { aproximity }^{j}+u^{j}
\end{aligned}
$$

For the productivity growth rate, the regression equations on the full sample and on each sub-sample are as following respectively:

$$
\begin{aligned}
& \text { aGDPpcgrowt } h^{j}=\alpha+\beta \text {.aproximity }{ }^{j}+\gamma \cdot\left(\text { aproximity }^{j}\right)^{2}+u^{j} \\
& \text { aGDPpcgrowt } h^{j}=\alpha+\beta \text {.aproximity }{ }^{j}+u^{j}
\end{aligned}
$$

Our strategy is to use the quadratic function for the full sample and the linear function on each sub-sample. On the full sample, the quadratic function can capture the non-linearity on the pattern of macroeconomic 
variables, including net total capital inflows, gross savings and productivity growth rate. On each sub-sample, the linear function can compare the pattern of international capital flows in the club of convergence with that pattern in the club of unconvergence. Therefore, the interaction of two functions helps us to visualize the transition of the pattern of each variable across two clubs of economies.

The empirical framework is convenient to investigate the long-run pattern of international capital flows. First, the cross-section analysis considers the average of variables over a 33-year period from 1980 to 2013. The time period is long enough to absorb the fluctuation of each variable over time. Gourinchas and Jeanne (2013), Alfaro, Kalemli-Ozcan, and Volosovych (2014) employ the same long-time period to generate a cross-section dataset to study the international capital flows. Second, the cross-section method focuses on the long-run equilibrium of net total capital inflows and the productivity growth rate. This constitutes the consistency between the evidence and the theory, since the theoretical model only focuses on the steady state. Third, the method is convenient to compare the pattern of capital flows across countries. In details, the countries

can differ by the proximity to world technology frontier. The cross-section analysis will consider the translation of these difference into the difference on the pattern of international capital flows. In brief, the combination of data and model can shed a light on the long-run pattern of international capital flows for a wide range of countries.

\subsection{Results.}

\subsubsection{U-Shaped Pattern of International Capital Flows.}

Figure (3) illustrates the dependence pattern of net total capital inflows on the productivity growth rate. The vertical line is at the productivity 
growth rate $(1.68 \%)$ of the world technology leader, i.e, United States. The line divides the full sample into two sub-samples: the club of unconvergence on the left of figure and the club of convergence on the right of figure. For the club of unconvergence, an increase of productivity growth rate is associated with less net total capital inflows. But, for the club of convergence, it is associated with more net total capital inflows. And this result holds even when dropping the observation with the productivity growth rate being greater than 8\%, such as China (CHN) and Guinea (GNQ). Therefore, the productivity growth rate at the world technology frontier can be an important factor to shape the pattern of international capital flows.

Figure 2: International Capital Flows and Productivity Growth Rate

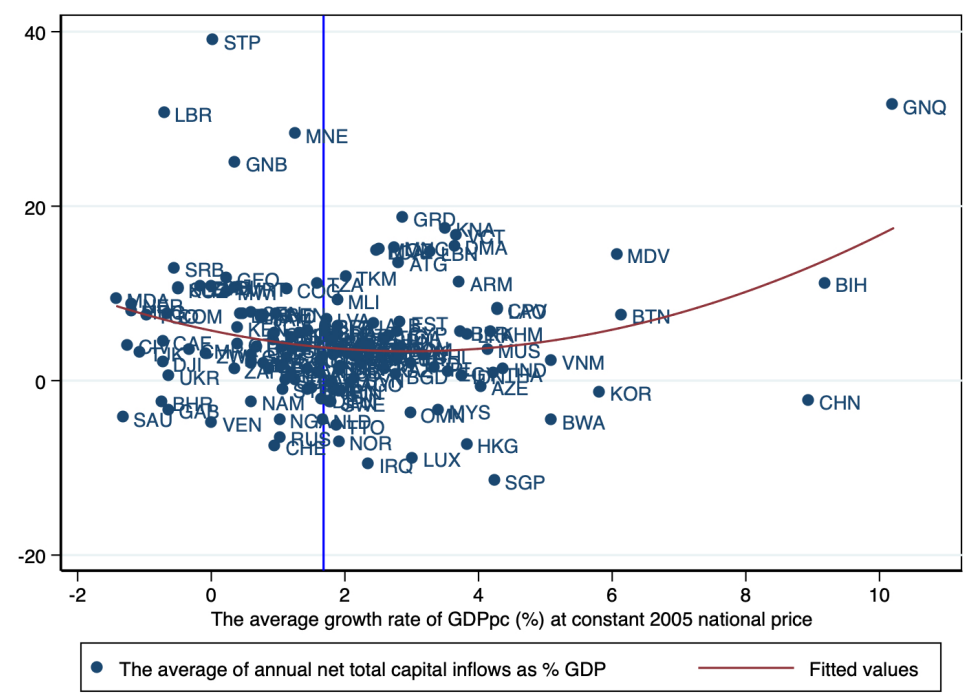

Table (2) shows the regression results of net total capital inflows on the productivity growth rate. On column 1, for the full sample, the pattern of net total capital inflows follows a quadratic function, by first decreasing then increasing on the productivity growth rate. Thus, the pattern of net total capital inflows can be imagined as an U-shaped curve, which combines two different linear patterns: a decreasing pattern is followed 
by an increasing one. Then, as suggested by Figure (1), we employ the productivity growth rate at the world technology frontier to separate these two patterns. On column (2), for the club of unconvergence, an increase of the productivity growth rate by $1 \%$ reduces the net total capital inflows by $-1.6 \%$. But, on column (3), for the club of convergence, it raises the net total capital inflows by $1.15 \%$. Therefore, the pattern of capital flows in the club of uncovergence diverges from their pattern in the club of convergence.

Table 2: Regression Results of Net Total Capital Inflows (anegCA2y) on Productivity Growth Rate: Full Sample (col.1), Club of Unconvergence (col.2) and Club of Convergence (col.3)

\begin{tabular}{|c|c|c|c|}
\hline VARIABLES & $\begin{array}{c}(1) \\
\text { anegCA2y }\end{array}$ & $\begin{array}{c}(2) \\
\text { anegCA2y }\end{array}$ & $\begin{array}{c}(3) \\
\text { anegCA2y }\end{array}$ \\
\hline $\begin{array}{l}\text { Productivity Growth Rate } \\
(a G D P \text { pcgrowth) }\end{array}$ & $\begin{array}{c}-1.598^{* * *} \\
(0.584)\end{array}$ & $\begin{array}{c}-1.612^{* *} \\
(0.714)\end{array}$ & $\begin{array}{l}1.151^{* *} \\
(0.442)\end{array}$ \\
\hline $\begin{array}{l}\text { Squared Value of (aGDPpcgrowth) } \\
\left(a G D P p c g r o w t h^{2}\right)\end{array}$ & $\begin{array}{l}0.269^{* * *} \\
(0.0806)\end{array}$ & & \\
\hline Constant & $\begin{array}{c}5.734^{* * *} \\
(0.890)\end{array}$ & $\begin{array}{c}4.461^{* * *} \\
(0.729)\end{array}$ & $\begin{array}{c}0.495 \\
(1.529)\end{array}$ \\
\hline $\begin{array}{l}\text { Observations } \\
\text { R-squared }\end{array}$ & $\begin{array}{c}158 \\
0.067\end{array}$ & $\begin{array}{c}50 \\
0.096\end{array}$ & $\begin{array}{c}87 \\
0.074\end{array}$ \\
\hline \multicolumn{4}{|c|}{ 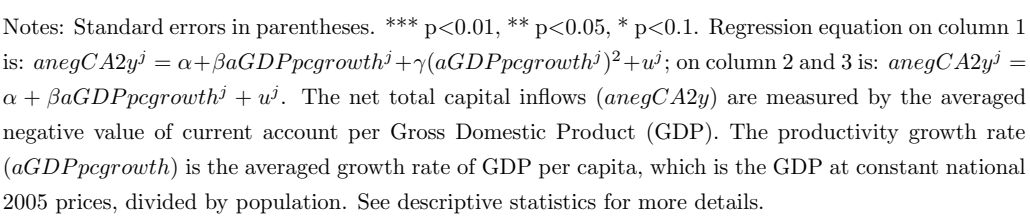 } \\
\hline
\end{tabular}

The distinctive feature on the divergence of net total capital inflows pattern is the transition from the decreasing pattern to the increasing one. In particular, on the club of unconvergence, an increase of productivity growth rate is associated with less net total capital inflows. When an economy improves its growth rate substantially to pass over the produc- 
tivity growth rate at the world technology frontier, it moves into the club of convergence. Then, its pattern of net total capital inflows turns to be increasing with respect to the productivity growth rate. Therefore, the productivity growth rate at the world technology frontier serves as the turning point of cross-border capital flows pattern.

\subsubsection{Proximity to World Technology Frontier and International Capital Flows.}

Figure 3: International Capital Flows and Proximity to World Technology Frontier

Panel A: Net Total Capital Inflows and Proximity to World Technology Frontier

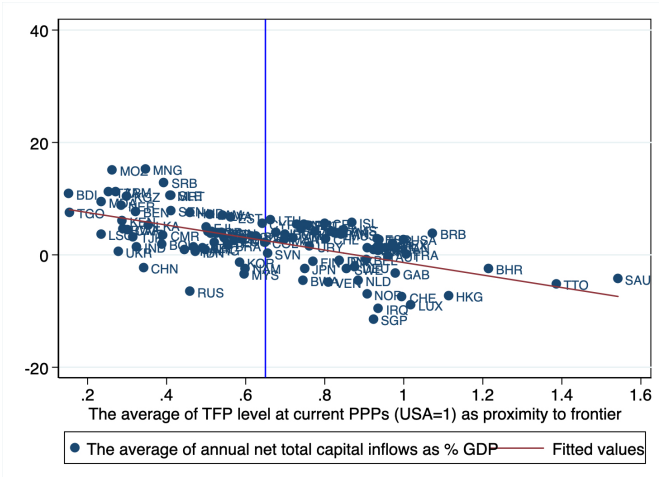

Panel B: Gross Savings and Proximity to World Technology Frontier

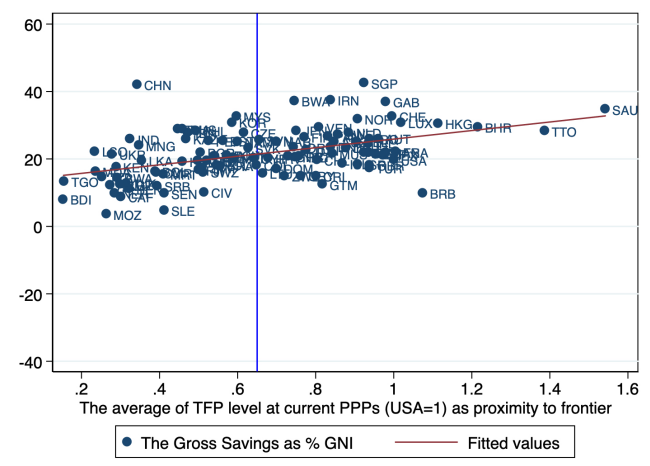

Figure (3) presents the dependence of net total capital inflows on the proximity to the world technology frontier. In Panel A, when an economy approaches the world technology frontier, it tends to receive less net total capital inflows. Since the net total capital inflows are the gap between domestic investment and savings, their decrease can be due to the increase of savings. Panel B shows that a closer proximity to world technology leader is associated with huger savings. Thus, the dependence pattern of net total capital inflows on the proximity to world technology frontier is underlined by the gross savings. 
Table (3) reports the regression results of net total capital inflows on the proximity to world technology frontier. For an economy approaches the world technology frontier, it tends to receive less net total capital inflows. In column 1, for the full sample, an increase of proximity to world technology frontier by 0.1 is associated with a reduction of net total capital inflows per output by $-11 \%$. For the club of convergence in column 2 , the reduction of net total capital inflows is by $10 \%$, while for club of unconvergence in column 3 , the magnitude of increase is higher, standing at $-12 \%$. In brief, the proximity to world technology frontier affects the pattern of cross-border capital flows.

Table 3: Regression Results of Net Total Capital Inflows (anegCA2y) on Proximity to World Technology Frontier: Full Sample (col.1), Club of Unconvergence (col.2) and Club of Convergence (col.3)

\begin{tabular}{|c|c|c|c|}
\hline VARIABLES & $\begin{array}{c}(1) \\
\text { anegCA2y }\end{array}$ & $\begin{array}{c}(2) \\
\text { anegCA2y }\end{array}$ & $\begin{array}{c}(3) \\
\text { anegCA2y }\end{array}$ \\
\hline $\begin{array}{l}\text { Proximity to World Technology Frontier } \\
\text { (aproximity) }\end{array}$ & $\begin{array}{c}-11.13^{* * *} \\
(1.427)\end{array}$ & $\begin{array}{c}-10.44^{* * *} \\
(2.050)\end{array}$ & $\begin{array}{c}-12.16^{* * *} \\
(2.437)\end{array}$ \\
\hline Constant & $\begin{array}{c}9.755^{* * *} \\
(1.021)\end{array}$ & $\begin{array}{c}9.732^{* * *} \\
(1.313)\end{array}$ & $\begin{array}{c}10.05^{* * *} \\
(1.813)\end{array}$ \\
\hline Observations & 106 & 50 & 54 \\
\hline R-squared & 0.369 & 0.351 & 0.324 \\
\hline
\end{tabular}

Table (4) reports the regression results of gross savings on the proximity to world technology frontier. In column 1 for the full sample, an increase of proximity to world technology frontier by 0.1 is associated with an increase of the savings per income by $12.7 \%$. In column 2 for club of unconvergence, 
the effect is larger with the coefficient of $13.71 \%$. The expansion of savings due to a closer proximity to word technology frontier also holds on the club of convergence on column 3. Its recorded coefficient is at $7.2 \%$, which is lower than the coefficient in the club of unconvergence on column 2. In brief, the domestic savings go up for an economy approaches the world technology frontier.

Table 4: Regression Results of Gross Savings ( $a S 2 G N I)$ on Proximity to World Technology Frontier: Full Sample (col.1), Club of Unconvergence (col.2) and Club of Convergence (col.3)

\begin{tabular}{|c|c|c|c|}
\hline VARIABLES & $\begin{array}{c}(1) \\
\text { aS2GNI }\end{array}$ & $\begin{array}{c}(2) \\
\text { aS2GNI }\end{array}$ & $\begin{array}{c}(3) \\
\text { aS2GNI }\end{array}$ \\
\hline $\begin{array}{l}\text { Proximity to World Technology Frontier } \\
\text { (aproximity) }\end{array}$ & $\begin{array}{c}12.70^{* * *} \\
(2.354)\end{array}$ & $\begin{array}{c}13.71^{* * *} \\
(3.092)\end{array}$ & $\begin{array}{l}7.212^{*} \\
(3.925)\end{array}$ \\
\hline Constant & $\begin{array}{c}13.19 * * * \\
(1.684)\end{array}$ & $\begin{array}{c}10.51 \\
(1.981)\end{array}$ & $\begin{array}{c}18.92^{* * *} \\
(2.920)\end{array}$ \\
\hline $\begin{array}{l}\text { Observations } \\
\text { R-squared }\end{array}$ & $\begin{array}{c}106 \\
0.219\end{array}$ & $\begin{array}{c}50 \\
0.291\end{array}$ & $\begin{array}{c}54 \\
0.061\end{array}$ \\
\hline \multicolumn{4}{|c|}{$\begin{array}{l}\text { Notes: Standard errors in parentheses. }{ }^{* * *} \mathrm{p}<0.01,{ }^{* *} \mathrm{p}<0.05,{ }^{*} \mathrm{p}<0.1 . \\
\text { Regression equation is: aS2GNI }=\alpha+\beta . I^{j}=\text { aprimity }^{j}+u^{j} \text {. The gross } \\
\text { savings }(a S 2 G N I \text { ) are measured by the averaged gross savings (including } \\
\text { both private and public savings) per Gross National Income (GNI). The } \\
\text { proximity to world technology frontier (aproximity) for one economy is the } \\
\text { averaged ratio of domestic productivity level over the productivity level of } \\
\text { United States. See descriptive statistics for more details. }\end{array}$} \\
\hline
\end{tabular}

Figure (4) depicts the dependence of productivity growth rate on the proximity to world technology frontier. The pattern of productivity growth rate in the club of unconvergence diverges from the one in the club of convergence. In details, a closer proximity to the world technology frontier is associated with an increase of the productivity growth rate on the club of 
unconvergence. But in the club of convergence, it is associated with a decrease of the productivity growth rate. Therefore, the productivity growth rate follows an inverse U-shaped pattern with respect to the proximity to world technology frontier.

Figure 4: Proximity to World Technology Frontier and Productivity Growth Rate

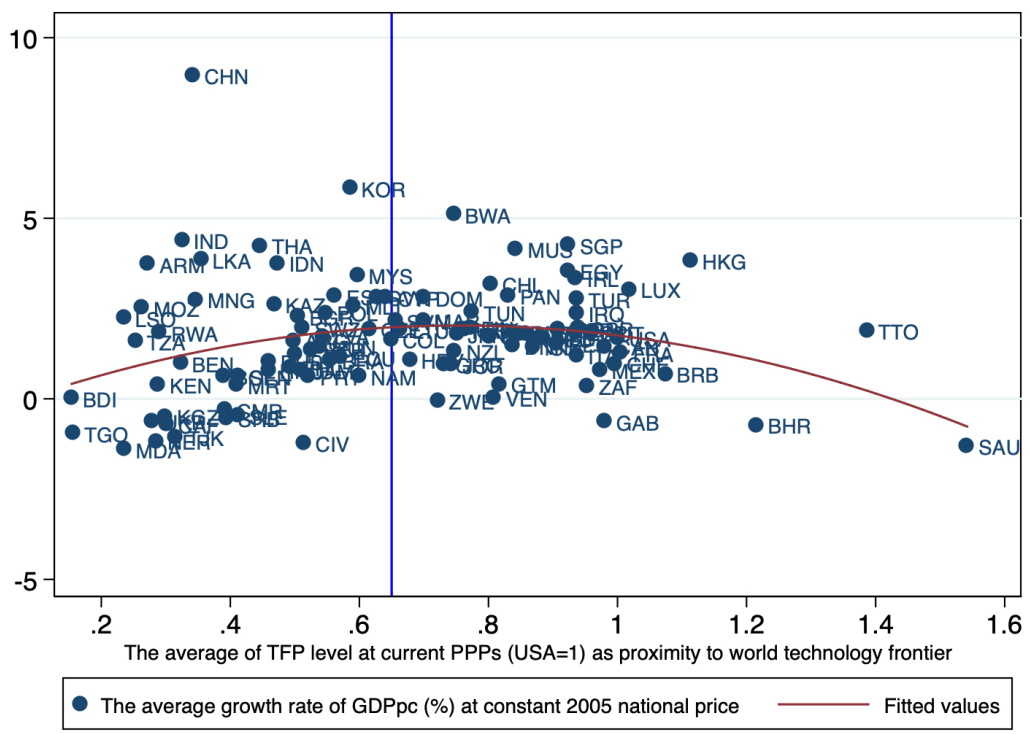

Table (5) shows the regression results of the productivity growth rate on the proximity to world technology frontier. In column 1, for the full sample of 106 economies, the productivity growth rate follows a quadratic function, depicted as an inverse U-shaped curve, by first increasing then decreasing on the proximity to world technology frontier. For a closer proximity to the world technology frontier, the productivity growth rate goes down for the 50-economies club of convergence (column 2), but goes up for the 54-economies club of unconvergence (column 3). In brief, the proximity to world technology frontier determines the productivity growth rate. 
Table 5: Regression Results of Productivity Growth Rate (aGDPpcgrowth) on Proximity to World Technology Frontier: Full Sample (col.1), Club of Unconvergence (col.2) and Club of Convergence (col.3)

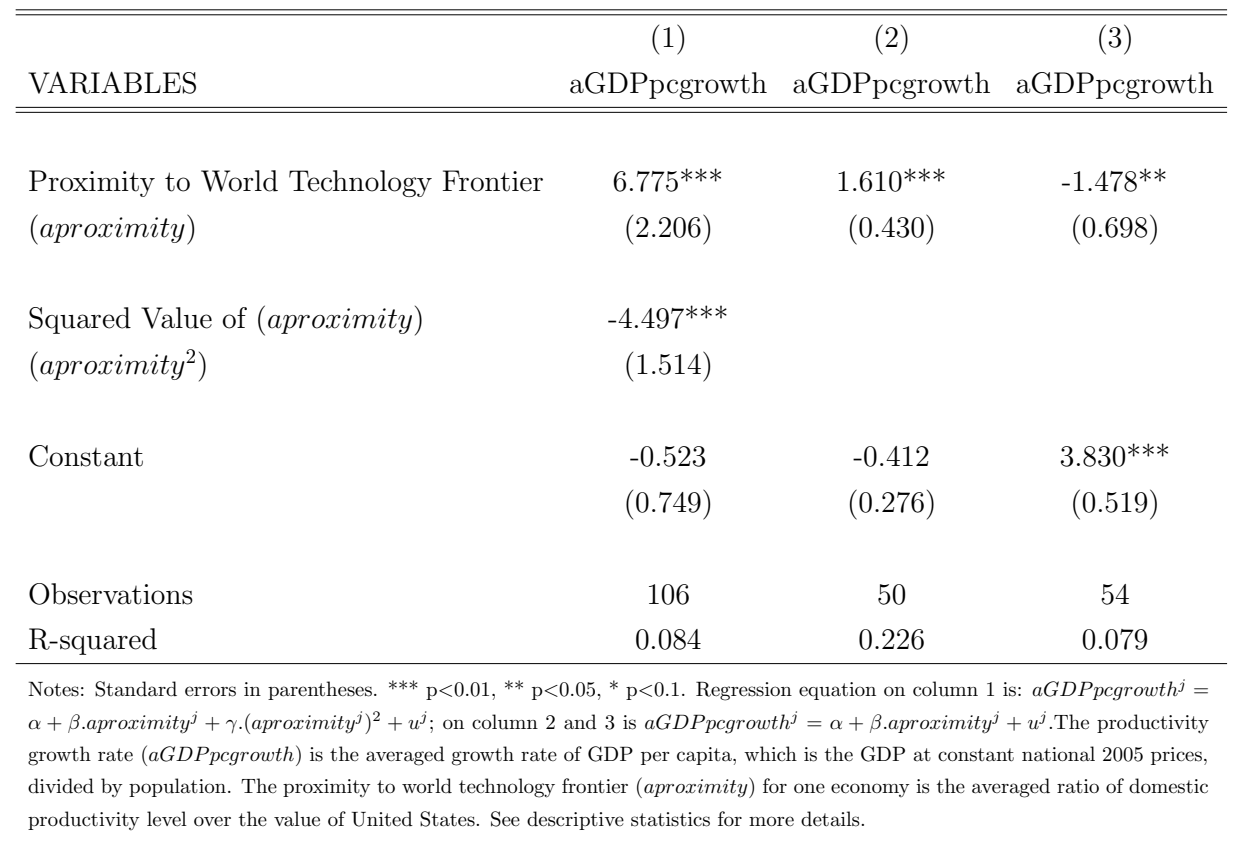

In sum, the empirical evidence shows that the proximity to world technology frontier shapes the pattern of international capital flows. On the full sample, the net total capital inflows are decreasing on the proximity to world technology frontier. In the club of unconvergence, the productivity growth rate surges for an economy is closer to the world technology frontier. Thus, in the club of unconvergence, a higher productivity growth rate is associated with less net total capital inflows. In the club of convergence, however, the productivity growth rate declines for an economy approaches the world technology frontier. Then, in this club, a higher productivity growth rate is associated with more net total capital inflows. Therefore, the proximity to world technology frontier underlines the divergence of international capital flows across the club of unconvergence and the club of convergence. 


\section{Theory.}

We build up a model to explain the decreasing pattern of net total capital inflows on the proximity to world technology frontier. We describe the economy, then characterize the interest rate at autarky steady state. The difference of autarky rate motivates the cross-border capital flows.

\subsection{Economy.}

The world economy includes many large open countries. Each country is populated with the overlapping generations of households who live for two periods: young and old. All countries use the same technology to produce one homogeneous good, which is used for consumption and investment, and is traded freely and costlessly. They also have the same structure and parameter values for the preferences and production technologies. The capital is free mobile but labor is immobile across countries. And firms are subject to changes in the domestic productivity levels and labor forces.

\subsubsection{Production and Investment.}

For an economy $j$, the output at time period $t$ is produced with constantreturn-to-scale technology, with parameter $(0<\alpha<1)$. The input includes the capital $\left(K_{t}\right)$ and labor force $\left(L_{t}\right)$.

$$
Y_{t}=K_{t}^{\alpha}\left(A_{t} L_{t}\right)^{\alpha}
$$

The total factor productivity $\left(A_{t}\right)$ is country-specific, and grows with an exogenous rate $\left(g_{t}^{A}\right)$ :

$$
A_{t+1}=\left(1+g_{t+1}^{A}\right) A_{t}
$$

The next-period capital stock is augmented by the current-period investment, plus the capital stock discounted by the depreciation rate $(\delta)$. 
The law of capital accumulation is as following:

$$
K_{t+1}=I_{t}+(1-\delta) K_{t}
$$

One representative firm hires the labor and capital to maximize the profit.

$$
\Pi_{t}=Y_{t}-R_{t} K_{t}-w_{t} L_{t}
$$

The perfect competition on the market for factors of production implies that each factor earns its marginal product. In term of capital-effectivelabor ratio $\left(k_{t} \equiv \frac{K_{t}}{A_{t} L_{t}}\right)$, the interest rate $\left(R_{t}\right)$ and wage rate $\left(w_{t}\right)$ are as following:

$$
\begin{aligned}
& R_{t}=\alpha k_{t}^{(\alpha-1)} \\
& w_{t}=(1-\alpha) A_{t} k_{t}^{\alpha}
\end{aligned}
$$

\subsubsection{Consumption and Savings.}

For one economy $j$, there are $N_{t}$ new-born agents at the time period $t$. The population is assumed to grow with an exogenous rate: $N_{t+1}=\left(1+g_{t+1}^{N}\right) N_{t}$. Each agent born at $t$ supplies one unit of labor to earn the competitive wage rate.

Let $\left(c_{t}^{y}\right)$ and $\left(c_{t+1}^{o}\right)$ denote her consumption at youth and old respectively. The lifetime utility of one agent born at $t$ is:

$$
U_{t}=u\left(c_{t}^{y}\right)+\beta u\left(c_{t+1}^{o}\right)
$$

whereby, the utility function follows the standard preferences $u(c)=\ln (c)$, and the discount factor $(\beta)$ satisfies $(0<\beta<1)$.

Let $\left(s_{t}^{y}\right)$ denote the saving at the end of period $t$ by one new-born agent. The sequence of budget constraints is as following:

$$
\begin{aligned}
c_{t}^{y}+s_{t}^{y} & =w_{t}(1-\tau) \\
c_{t+1}^{o} & =R_{t+1} s_{t}^{y}
\end{aligned}
$$


When young, an agent works for the wage rate $\left(w_{t}\right)$ and covers the income taxation $(\tau)$. She allocates the income between consumption and saving. At old, she receives the interest rate on savings and consume all income.

With log utility function, the saving is a constant fraction of disposable income, which is the income after taxation duty fulfillment.

$$
s_{t}^{y}=\frac{\beta}{(1+\beta)}(1-\tau) w_{t}
$$

\subsubsection{R\&D Expenditure and Productivity Growth.}

Let $\left(Z_{t}\right)$ denote the public expenditure on the Research and Development (R\&D) by the government in country $(j)$. We assume that the balanced public budget holds for all time period. Therefore, the income tax revenue equals to the $R \& D$ expenditure:

$$
\tau w_{t}=Z_{t}
$$

Let $\left(\bar{A}_{t}\right)$ denotes the productivity level at the world technology frontier: $\bar{A}_{t} \equiv \max _{j}\left(A_{t}^{j}\right)$. As on Aghion and Howitt (2008), the productivity growth rate is assumed to depend on the target level of productivity, which is, in our model, given by the technology level at the world technology frontier. With a concave function $\phi($.$) , we have:$

$$
g_{t}^{A}=\phi\left(\frac{Z_{t}}{\bar{A}_{t}}\right)
$$

Moreover, we also employ the following assumption.

Assumption 3.1.1. For country $j$, the RED expenditure and productivity level grow with the same rate, given by the world technology frontier. And 
all countries have the same R\&D expenditure $\left(Z_{t}^{j}=Z_{t}, \forall j\right)$.

$$
\begin{aligned}
\bar{A}_{t} & =\left(1+g_{t}^{A}\right) \bar{A}_{t-1} \\
A_{t}^{j} & =\left(1+g_{t}^{A}\right) A_{t-1}^{j} \\
Z_{t} & =\left(1+g_{t}^{A}\right) Z_{t-1}
\end{aligned}
$$

By this assumption, both the ratio of $\mathrm{R} \& \mathrm{D}$ expenditure over world technology frontier $\left(Z_{t} / \bar{A}_{t}\right)$ and the proximity to world frontier are constant over time for each country: $Z_{t}^{j} / \bar{A}_{t}=Z / \bar{A}, \forall t, \forall j ; A_{t}^{j} / \bar{A}_{t}=A^{j} / \bar{A}, \forall t$. The proximity to world technology frontier is different across countries: $A_{t}^{j} / \bar{A}_{t} \neq A_{t}^{h} / \bar{A}_{t}, \forall j \neq h$, whereby, $\left(Z, A^{j}, \bar{A}\right)$ are the initial values. But the productivity growth rate (12) is the same across countries, since they have the same $R \& D$ expenditure.

The assumption is employed to keep the model to be tractable. The symmetric growth rate across countries implies that the share of each country's total effective units of labor over world total effective units of labor is constant. For each variable, since its world value is the weighted average of each country's value, the constant share facilitates the computation of world value. Recently, Coeurdacier, Guibaud and Jin (2015) also employ the symmetric productivity growth rate on a multi-country OLG model.

By using (9) to rewrite the public budget balance (11), the tax rate is a function of the proximity to frontier $\left(\frac{A_{t}}{\bar{A}_{t}}\right)$.

$$
\tau k_{t}^{\alpha}=\frac{1}{(1-\alpha)} \frac{Z}{\bar{A}} \frac{\bar{A}}{A}
$$

\subsection{International Capital Flows.}

\subsubsection{Equilibrium.}

\section{Autarky.}

At autarky, the savings are equal to the investment $\left(S_{t}^{y} \equiv N_{t} s_{t}^{y}=I_{t}\right)$. 
Using the saving rate (10), the wage rate (9), and share of labor income over output $\left(w_{t} N_{t}=(1-\alpha) Y_{t}\right)$, the savings account for a constant fraction of output:

$$
S_{t}^{y}=\frac{\beta}{(1+\beta)}(1-\tau)(1-\alpha) Y_{t}
$$

Replacing the last equation on the law of capital accumulation (7), we get the long-run equilibrium capital-effective-labor ratio. The autarky steady state with perfect foresight is on the following Theorem.

$$
\left(1+g_{t+1}^{A}\right)\left(1+g_{t+1}^{N}\right) k_{t+1}=\frac{\beta}{(1+\beta)}(1-\alpha)(1-\tau) k_{t}^{\alpha}+(1-\delta) k_{t}
$$

Theorem 3.2.1. There exists an unique, stable steady state for an autarky economy. At steady state, $\frac{\partial R}{\partial\left(1+g^{A}\right)}>0 ; \frac{\partial R}{\partial\left(1+g^{N}\right)}>0$.

Proof. Appendix

At steady state $\left(k_{t+1}=k_{t}=k\right)$, the interest rate given by (8) as:

$$
R=\frac{\alpha}{(1-\alpha)} \frac{(1+\beta)}{\beta} \frac{\left(1+g^{A}\right)\left(1+g^{N}\right)-1+\delta}{(1-\tau)}
$$

By the implicit function theorem for public budget (13) at steady state, we have:

$$
\tau k(\tau)^{\alpha}=\frac{1}{(1-\alpha)} \frac{Z}{\bar{A}} \frac{\bar{A}}{A} \Rightarrow \frac{\partial \tau}{\partial(A / \bar{A})}<0
$$

The tax rate is decreasing on the proximity to world technology frontier. In details, for an economy approaches the world technology frontier, its productivity level goes up. By (9), the wage rate also increases. Then, the tax rate needed to finance a given $R \& D$ expenditure goes down.

For an economy is closer to the world technology frontier, it has a lower tax rate, and a higher disposable income. With a constant marginal saving rate, the aggregate savings stock goes up, then, depressing the autarky interest rate. Therefore, one economy being closer to world technology frontier would have a lower interest rate, as on the following Lemma. 
Lemma 3.2.1. At autarky steady state, one economy $j$ being closer to the world technology frontier would have a huger domestic gross savings stock and a lower interest rate.

$$
\frac{\partial\left(S^{y} / Y\right)}{\partial(A / \bar{A})}>0 ; \frac{\partial R}{\partial A / \bar{A}}<0
$$

Proof. By (14) and (16), we have:

$$
\frac{\partial\left(S^{y} / Y\right)}{\partial(A / \bar{A})}=\frac{\partial\left(S^{y} / Y\right)}{\partial \tau} \frac{\partial \tau}{\partial(A / \bar{A})}>0
$$

By (15), we have:

$$
\frac{\partial R}{\partial A / \bar{A}}=\left(\left(1+g^{A}\right)\left(1+g^{N}\right)-1+\delta\right) \frac{\partial \tau}{\partial(A / \bar{A}}
$$

Since $\frac{\partial \tau}{\partial(A / \bar{A}}<0, \frac{\partial R}{\partial A / \bar{A}}<0$.

\section{Integration.}

At integration, the world capital market clearing condition requires that total savings are equal to total investment: $\Sigma_{j} S_{t}^{y, j}=\Sigma_{j} I_{t}^{j}$. And the law of capital accumulation at integration is as following:

$$
\Sigma_{j} K_{t+1}^{j}=\Sigma_{j} S_{t}^{j}+(1-\delta) \Sigma_{j} K_{t}^{j}
$$

The free mobility of capital implies that the capital-effective-labor ratio is equalized across countries: $k_{t}^{j}=k_{t}^{w}, \forall j$. And the integration capital accumulation level at the long-run satisfies the equation:

$$
\left(1+g_{t+1}^{A}\right)\left(1+g_{t+1}^{N}\right) k_{t+1}^{w}=\frac{\beta}{(1+\beta)}(1-\alpha)(1-\bar{\tau})\left(k_{t}^{w}\right)^{\alpha}+(1-\delta) k_{t}^{w}
$$

whereby, the world average tax rate is $\bar{\tau} \equiv \Sigma_{j} \lambda_{j} \tau^{j}$, with the constant share $\lambda^{j} \equiv \frac{A_{t}^{j} N_{t}^{j}}{\Sigma A_{t}^{j} N_{t}^{j}}$, given the symmetric growth rates across countries implied by the Assumption 3.1.1. 
Theorem 3.2.2. There exists an unique, stable steady state for an integration economy. At steady state, $\min _{\left(A^{j} / \bar{A}\right)} R^{j}\left(A^{j} / \bar{A}\right)<R^{w}<\max$ ${ }_{\left(A^{j} / \bar{A}\right)} R^{j}\left(A^{j} / \bar{A}\right)$.

Proof. Appendix

At world integration steady state, the world interest rate depends on the economic growth and average tax rate:

$$
R^{w}=\frac{\alpha}{(1-\alpha)} \frac{(1+\beta)}{\beta} \frac{\left(1+g^{A}\right)\left(1+g^{N}\right)-1+\delta}{(1-\bar{\tau})}
$$

The existence of a common world interest rate underlies the crossborder capital flows. In particular, the capital flows from the economy with low autarky interest rate to the one with high autarky interest rate. The flow of capital would end only when the domestic interest rate and the corresponding capital-effective-labor ratio is equalized across countries. We apply this principle to analyze the pattern of international capital flows on the next section.

\subsubsection{Pattern of International Capital Flows.}

The aggregate savings stock of the young (i.e, $S_{t}^{y} \equiv N_{t} s_{t}^{y}$ ) has two components, the net foreign assets $\left(B_{t+1}\right)$ and the capital stock used in the production in the next period $\left(K_{t+1}\right)$. According to Obstfeld and Rogoff (1996),

$$
S_{t}^{y}=B_{t+1}+K_{t+1}
$$

By dividing both side of previous equation by the next-period output, we have:

$$
\frac{B_{t+1}}{Y_{t+1}}=\frac{S_{t}^{y}}{Y_{t}} \frac{Y_{t}}{Y_{t+1}}-\frac{K_{t+1}}{Y_{t+1}}
$$

Replacing the gross savings stock (14), the growth rate of output (i.e, $\left.Y_{t+1} / Y_{t}=\left(1+g_{t+1}^{A}\right)\left(1+g_{t+1}^{N}\right)\right)$, and the capital income share $\left(R_{t+1}^{w} K_{t+1}=\right.$ 
$\left.\alpha Y_{t+1}\right)$, we get the ratio of net stock of foreign assets over output as:

$$
\frac{B_{t+1}}{Y_{t+1}}=\frac{\beta}{(1+\beta)} \frac{(1-\alpha)(1-\tau)}{\left(1+g_{t+1}^{A}\right)\left(1+g_{t+1}^{N}\right)}-\frac{\alpha}{R_{t+1}^{w}}
$$

At steady state with a constant growth rate of productivity and labor force $\left(g_{t}^{A}=g^{A}, g_{t}^{N}=g^{N}, \forall t\right)$, the net foreign assets at the beginning of period is also constant.

$$
\frac{B}{Y}=\frac{\beta}{(1+\beta)} \frac{(1-\alpha)(1-\tau)}{\left(1+g^{A}\right)\left(1+g^{N}\right)}-\frac{\alpha}{R^{w}}
$$

Replacing the world interest rate (17) into (18), the steady-state net foreign assets with full depreciation $(\delta=1)$ are as following.:

$$
\frac{B}{Y}=\frac{\beta}{(1+\beta)} \frac{(1-\alpha)(\bar{\tau}-\tau(A / \bar{A}))}{\left(1+g^{A}\right)\left(1+g^{N}\right)}
$$

The current account is the changes in the net stock of foreign assets, i.e, $\left(C A_{t}=B_{t+1}-B_{t}\right)$.

$$
\frac{C A_{t}}{Y_{t}}=\frac{B_{t+1}}{Y_{t+1}} \frac{Y_{t+1}}{Y_{t}}-\frac{B_{t}}{Y_{t}}
$$

Evaluating the current account (20) at steady state, then using the net foreign assets $(19)$, we get the net total capital inflows, which are measured by negative value of current account, as following:

$$
\begin{aligned}
-\frac{C A}{Y} & =\left(g^{A}+g^{N}+g^{A} g^{N}\right)\left(-\frac{B}{Y}\right) \\
& =\frac{\beta}{(1+\beta)} \frac{(1-\alpha)\left(g^{A}+g^{N}+g^{A} g^{N}\right)}{\left(1+g^{A}\right)\left(1+g^{N}\right)}\left(\tau\left(A^{j} / \bar{A}\right)-\bar{\tau}\right)
\end{aligned}
$$

The net total capital inflows depend on the proximity to the world technology frontier. For a closer proximity to the world technology frontier, i.e, a higher $\left(A^{j} / \bar{A}\right)$, the income tax rate goes down. This reduces the gap between domestic and world average tax rate, i.e, $\left(\tau\left(A^{j} / \bar{A}\right)-\bar{\tau}\right)$. Then, the net total capital inflows decrease. The result is summarized on the following proposition. 
Proposition 3.2.1. At the integration steady state, an economy being closer to the world technology frontier has less net total capital inflows:

$$
-\frac{C A^{j}}{Y^{j}}<-\frac{C A^{h}}{Y^{h}} \Leftrightarrow \frac{A^{j}}{\bar{A}}>\frac{A^{h}}{\bar{A}}, \forall j \neq h
$$

Proof. The proof is directly derived by using (21). We have:

$$
\frac{\partial\left(-C A^{j} / Y^{j}\right)}{\partial\left(A^{j} / \bar{A}\right)}=\frac{\beta}{(1+\beta)} \frac{(1-\alpha)\left(g^{A}+g^{N}+g^{A} g^{N}\right)}{\left(1+g^{A}\right)\left(1+g^{N}\right)}\left(1-\lambda^{j}\right) \frac{\partial \tau^{j}}{\partial\left(A^{j} / \bar{A}\right)}<0
$$

The dependence of net total capital inflows on the proximity to world technology frontier relies on the domestic savings stock. For an economy is closer to world technology frontier (i.e, a higher $A^{j} / \bar{A}$ ), the disposable income increases, which, in turn, raises the savings stock. With a given investment demand, the autarky interest rate goes down. Then, the economy makes the foreign investment to the rest of world in seeking a higher rate of return. Therefore, its net total capital inflows decrease for an economy approaches the world technology frontier.

\section{Conclusion.}

We combine the evidence and theory to investigate the pattern of international capital flows. On the club of convergence, a closer proximity to the world technology frontier reduces both net total capital inflows and productivity growth rate. Hence, the inflows of capital are positively correlated to the productivity growth rate. On the club of unconvergence, a closer proximity to the world technology frontier reduces the net total capital inflows but raises the productivity growth rate. Thus, the inflows of capital are negatively correlated to the productivity growth rate.

For the policy implication, only when an economy belongs to the club 
of convergence, it receives more net total capital inflows for an improvement of productivity growth rate. In particular, the required productivity growth rate is $1.68 \%$, which is the value of the world technology leader.

Otherwise, on the club of unconvergence, an economy tends to receive less net total capital inflows for a higher productivity growth rate.

On the future research avenue, we can decompose the net total capital inflows into public and private flows. Gourinchas and Jeanne (2013) show that, for a higher productivity growth rate, the net public capital inflows decrease while the private capital inflows increase.

\section{References}

Acemoglu, Daron, Philippe Aghion, and Fabrizio Zilibotti. "proximity to frontier, selection, and economic growth." Journal of the European Economic association 4.1 (2006): 37-74.

Aghion, Philippe, and Peter W. Howitt. The economics of growth. MIT press, 2008.

Aghion, Philippe, Peter Howitt, and David Mayer-Foulkes. "The effect of financial development on convergence: Theory and evidence." The Quarterly Journal of Economics 120.1 (2005): 173-222.

Alfaro, Laura, Sebnem Kalemli-Ozcan, and Vadym Volosovych. "Sovereigns, upstream capital flows, and global imbalances." Journal of the European Economic Association 12.5 (2014): 1240-1284.

Alfaro, Laura, Sebnem Kalemli-Ozcan, and Vadym Volosovych. "Why doesn't capital flow from rich to poor countries? An empirical investigation." The review of economics and statistics 90.2 (2008): 347368. 
Benhima, Kenza. "A reappraisal of the allocation puzzle through the portfolio approach." Journal of international Economics 89.2 (2013): $331-346$.

Caballero, Ricardo J., Emmanuel Farhi, and Pierre-Olivier Gourinchas. "An equilibrium model of" global imbalances" and low interest rates." American economic review 98.1 (2008): 358-93.

Carroll, Christopher D., and David N. Weil. "Saving and growth: a reinterpretation." Carnegie-Rochester conference series on public policy. Vol. 40. North-Holland, 1994.

Coeurdacier, Nicolas, Stéphane Guibaud, and Keyu Jin. "Credit constraints and growth in a global economy." The American Economic Review 105.9 (2015): 2838-2881.

Chatterjee, Sirsha, and Kanda Naknoi. "The marginal product of capital, capital flows, and convergence." American Economic Review 100.2 (2010): 73-77.

Escot, Lorenzo, and Miguel-Angel Galindo. "International capital flows and convergence in the neoclassical growth model." International Advances in Economic Research 6.3 (2000): 451-460.

Galindo, Miguel-Angel, and Lorenzo Escot. "International capital flows, convergence and growth." The Journal of Economic Asymmetries 1.1 (2004): 49-69.

Gourinchas, Pierre-Olivier, and Olivier Jeanne. "Capital flows to developing countries: The allocation puzzle." The Review of Economic Studies (2013). 
Gourinchas, Pierre-Olivier, and Hélène Rey. "External adjustment, global imbalances, valuation effects." Handbook of International Economics. Vol. 4. Elsevier, 2014. 585-645.

Ly Dai Hung. "Non-linear pattern of international capital flows." Review of World Economics (2019), 155(3), 575-600.

Ly Dai Hung. "Empirics for Marginal Product of Capital." Journal of International Commerce, Economics and Policy (2019): 2050003.

Lane, Philip R., and Gian Maria Milesi-Ferretti. "The external wealth of nations mark II: Revised and extended estimates of foreign assets and liabilities, 1970-2004." Journal of international Economics 73.2 (2007): 223-250.

Matsuyama, Kiminori. "Financial market globalization, symmetrybreaking, and endogenous inequality of nations." Econometrica 72.3 (2004): 853-884.

Obstfeld, Maurice, and Kenneth S. Rogoff. Foundations of international macroeconomics. Vol. 30. Cambridge, MA: MIT press, 1996.

Parker, Jonathan A., and Bruce Preston. "Precautionary saving and consumption fluctuations." American Economic Review 95.4 (2005): 1119-1143.

Prasad, Eswar S., Raghuram G. Rajan, and Arvind Subramanian. Foreign capital and economic growth. No. w13619. National Bureau of Economic Research, 2007.

Solow, Robert M. "A contribution to the theory of economic growth." The quarterly journal of economics 70.1 (1956): 65-94. 


\section{A Appendix.}

\section{A.1 Definition of Equilibrium.}

\section{Definition A.1.1. The autarky temporal equilibrium.}

Given the value determined by the last period $\left(s_{t-1}^{y}, I_{t-1}=N_{t-1} s_{t-1}^{y}\right)$ and the expected interest rate $\left(R_{t+1}^{e}\right)$, the temporary equilibrium of time $t$ is a list of prices (interest rate $R_{t}$, wage rate $w_{t}$ ) and individual allocations $\left(c_{t}^{y}, c_{t}^{o}, s_{t}^{y}\right)$, aggregate variables $\left(K_{t}, L_{t}, Y_{t}, k_{t}, I_{t}, Z_{t}\right)$ such that:

1. Profit is maximized and Utility is maximized subjected to budget constraints.

2. Market clearing conditions are satisfied:

a Labor market: $L_{t}=N_{t}$

b Capital market: $I_{t}=S_{t}^{y} \equiv N_{t} s_{t}^{y}$

$c$ Good market: $N_{t} c_{t}^{y}+N_{t} s_{t}^{y}+N_{t-1} c_{t}^{o}+Z_{t}=Y_{t}$

\section{Definition A.1.2. The autarky inter-temporal equilibrium.}

Given an initial capital stock $\left(k_{0}=K_{0} /\left(A_{t-1} N_{-1}\right)\right)$, an autarky intertemporal equilibrium with perfect foresight is a sequence of temporary equilibria that satisfies for all $t>0$ the conditions that:

$$
\begin{aligned}
R_{t+1}^{e} & =R_{t+1}=\alpha k_{t+1}^{(\alpha-1)} \\
\left(1+g^{A}\right)\left(1+g^{N}\right) k_{t+1} & =N_{t} s^{y}\left(w\left(k_{t}\right), \tau, R_{t+1}\right)+(1-\delta) k_{t}
\end{aligned}
$$

\section{Definition A.1.3. The integration temporal equilibrium.}

At each country $j$, given the value determined by the last period $\left(s_{t-1}^{y, j}, \Sigma_{j} I_{t-1}^{j}=\right.$ $\left.\Sigma_{j} N_{t-1}^{j} s_{t-1}^{y, j}\right)$ and the expected interest rate $\left(R_{t+1}^{e, j}\right)$, the temporary equilibrium of time $t$ is a list of world interest rate $\left(R_{)}^{w}\right.$, domestic wage rate $\left(w_{t}^{j}\right)$, and 
individual allocations $\left(c_{t}^{y, j}, c_{t}^{o, j}, s_{t}^{y, j}\right)$, aggregate variables $\left(K_{t}^{j}, L_{t}^{j}, Y_{t}^{j}, k_{t}^{w}, I_{t}^{j}, Z_{t}^{j}\right)$ such that:

1. Profit is maximized and Utility is maximized subjected to budget constraints at country $j$.

2. Market clearing conditions are satisfied:

a Labor market at each country $j: L_{t}^{j}=N_{t}^{j}$

$b$ World Capital market: $\Sigma_{j} I_{t}^{j}=\Sigma_{j} S_{t}^{y, j}=\Sigma_{j} N_{t}^{j} s_{t}^{y, j}$

$c$ World Good market: $\Sigma_{j}\left(N_{t}^{j} c_{t}^{y, j}+N_{t}^{j} s_{t}^{y, j}+N_{t-1}^{j} c_{t}^{o, j}+Z_{t}^{j}\right)=\Sigma_{j} Y_{t}^{j}$

\section{Definition A.1.4. The integration inter-temporal equilibrium.}

Given an initial world capital stock $\left(k_{0}^{w}=\Sigma_{j} K_{0}^{j} / \Sigma_{j}\left(A_{-1}^{j} N_{-1}^{j}\right)\right)$, an integration inter-temporal equilibrium with perfect foresight is a sequence of temporary equilibria that satisfies for all $t>0$ the conditions that:

$$
\begin{aligned}
R_{t+1}^{e, w} & =R_{t+1}^{w}=\alpha\left(k_{t+1}^{w}\right)^{(\alpha-1)} \\
\left(1+g^{A}\right)\left(1+g^{N}\right) k_{t+1}^{w} & =\Sigma_{j} N_{t}^{j} s^{y}\left(w^{j}\left(k_{t}^{w}\right), \tau^{j}, R_{t+1}^{w}\right)+(1-\delta) k_{t}^{w}
\end{aligned}
$$

\section{A.2 Proofs.}

We prove the Theorem (3.2.2). The proof for Theorem (3.2.1) is the similar, for one closed economy.

Theorem 2.2.2. There exists an unique, stable steady state for an integration economy. At steady state, $\min _{\left(A^{j} / \bar{A}\right)} R^{j}\left(A^{j} / \bar{A}\right)<R^{w}<\max _{\left(A^{j} / \bar{A}\right)} R^{j}\left(A^{j} / \bar{A}\right)$.

Proof. The law of capital accumulation at the world integration economy:

$$
k_{t+1}^{w}=\frac{1}{\left(1+g_{t+1}^{A}\right)\left(1+g_{t+1}^{N}\right)}\left(\frac{\beta}{(1+\beta)}(1-\alpha)(1-\bar{\tau})\left(k_{t}^{w}\right)^{\alpha}+(1-\delta) k_{t}^{w}\right)
$$


1. Existence.

Define $\Delta \equiv k_{t+1}^{w}-\frac{1}{\left(1+g_{t+1}^{A}\right)\left(1+g_{t+1}^{N}\right)}\left(\frac{\beta}{(1+\beta)}(1-\alpha)(1-\bar{\tau})\left(k_{t}^{w}\right)^{\alpha}+\right.$ $\left.(1-\delta) k_{t}^{w}\right)$

We have:

$$
\lim _{k_{t+1}^{w} \rightarrow 0} \Delta<0 ; \lim _{k_{t+1}^{w} \rightarrow \infty} \Delta>0
$$

$\Rightarrow$ There exist the solution for the equation: $\Delta=0$.

2. Uniqueness.

Let define $G\left(k_{t}^{w}\right) \equiv\left(\frac{1}{\left(1+g_{t+1}^{A}\right)\left(1+g_{t+1}^{N}\right)} \frac{\beta}{(1+\beta)}(1-\alpha)(1-\bar{\tau})\left(k_{t}^{w}\right)^{\alpha}+\right.$ $\left.(1-\delta) k_{t}^{w}\right)$, as the function of $\left(k_{t+1}^{w}\right)$ with respect to $\left(k_{t}^{w}\right)$.

We have

$\left.\frac{\partial G\left(k_{t}^{w}\right)}{\partial k_{t}^{w}}=\frac{1}{\left(1+g_{t+1}^{A}\right)\left(1+g_{t+1}^{N}\right)}\left(\frac{\beta}{1+\beta} \alpha(1-\alpha)(1-\bar{\tau}) k_{t}^{w}(\alpha-1)+1-\delta\right)\right)>0$

$\Rightarrow G\left(k_{t}^{w}\right)$ is a monotonic increasing function, which converges to one positive value if any.

3. Global stability.

For $0<\alpha<1,0<\delta<1$, we have:

$$
\begin{aligned}
\lim _{k_{t}^{w} \rightarrow \infty} \frac{k_{t+1}^{w}}{k_{t}^{w}} & =\lim _{k_{t}^{w} \rightarrow \infty} \frac{1}{\left(1+g_{t+1}^{A}\right)\left(1+g_{t+1}^{N}\right)}\left(\frac{\beta}{1+\beta}(1-\alpha)(1-\bar{\tau}) k_{t}^{w(\alpha-1)}+1-\delta\right) \\
& =\frac{(1-\delta)}{\left(1+g^{A}\right)\left(1+g^{N}\right)}<1
\end{aligned}
$$

$\Rightarrow$ The curve of $G\left(k_{t}^{w}\right)$ is below the 45 degree line for a large enough value of $\left(k_{t}^{w}\right)$. Thus, the solution for the equation $(\Delta=0)$ is stable. 
For the world interest rate, we have:

$$
\begin{aligned}
\frac{1}{R^{w}} & =\frac{(1-\alpha)}{\alpha} \frac{\beta}{(1+\beta)} \frac{(1-\bar{\tau})}{\left(1+g^{A}\right)\left(1+g^{N}\right)-1+\delta} \\
& =\Sigma_{j} \lambda^{j} \frac{(1-\alpha)}{\alpha} \frac{\beta}{(1+\beta)} \frac{\left(1-\tau^{j}\left(A^{j} / \bar{A}\right)\right)}{\left(1+g^{A}\right)\left(1+g^{N}\right)-1+\delta}=\Sigma_{j} \lambda^{j}\left(\frac{1}{R^{j}}\right) \\
\Rightarrow \min \left(\frac{1}{R^{j}}\right) & <\frac{1}{R^{w}}<\max \left(\frac{1}{R^{j}}\right) \Rightarrow \min _{\left(A^{j} / \bar{A}\right)} R^{j}\left(A^{j} / \bar{A}\right)<R^{w}<\max _{\left(A^{j} / \bar{A}\right)} R^{j}\left(A^{j} / \bar{A}\right)
\end{aligned}
$$

